\title{
Guest Editors' foreword: democracies at war
}

\author{
John Kane and Haig Patapan
}

How does democracy, with its distinctive norms and institutions, shape the politics that occur at the intersection of international and domestic spheres? This question has received extensive attention from students of international relations, but almost exclusively in one specific context: that of war and peace. What is generally known as democratic peace theory has explored, with increasing sophistication, the propensity of democracies to wage wars, or alternatively to refrain from waging wars, both against other democracies and against nondemocratic regimes.

This special edition revisits some of the themes of this scholarship but also addresses theoretical and empirical questions that go beyond the existing literature. ${ }^{1}$ Before we outline the specific contribution of the articles in this special edition, it is useful to indicate briefly the major issues that shape the contours of this scholarship.

\section{Addressing the question of democracy and war}

It is not possible adequately to summarise the large international relations scholarship on democracy and war, but we may usefully adumbrate it by noting that three methodological strands have been distinguished as guiding inquiry. According to George and Bennett (2005), these have roughly succeeded one another over time.

The first generation of empirical research, from 1960s through the late 1980s, relied on statistical methods to assess correlations between regime types and war. It yielded the important finding that, although democracies are as likely as other regimes to engage in war, they rarely, if ever, fight wars against each other. To use the terms employed in the literature, while a 'dyadic peace' seems to hold between democratic states there is no apparent tendency toward 'monadic' democratic peacefulness (which would be indicated if democracies proved statistically unwilling to go to war with anyone). ${ }^{2}$ Statistical research to establish causal mechanisms behind the inter-democratic peace were, however, less successful in this period

\footnotetext{
${ }^{1}$ Research for this paper was supported by an Australian Research Council Discovery Grant. We are grateful to Dan Halvorson and Lee Morgenbesser for able research assistance.

${ }^{2}$ See Rummel (1979); Chan (1984); Weede (1984); Doyle (1983); Maoz and Abdolali (1989); Moaz and Russett (1993); Rousseau et al. (1996). On the monadic theory regarding states in transition to democracy see Snyder and Mansfield (1995) and Rousseau et al. (1996).
} 
(Maoz and Russett 1993; Dixon 1994), due to a variety of measurement problems, statistical biases and the limited number of cases. ${ }^{3}$

In the second generation of research, the principal focus consequently shifted from the 'whether' to the 'why' of democratic peace. In attempting to answer this 'why' question, some of the most influential scholars turned to the political works of Immanuel Kant, whose liberal internationalism had set the terms of the research agenda by arguing that international peace among states depended on a combination of widespread republican government, economic interdependence and institutionalised international law. ${ }^{4}$ Empirical testing of causal mechanisms in this period was pursued more directly by case studies and 'process tracing.' Case studies proved especially useful for testing new variables, though no consensus was reached on which mechanisms might account for the dyadic democratic peace. ${ }^{5}$

The third and most recent wave of scholarship used formal models and both statistical and case study research to clarify how democratic institutions might constrain democratic foreign policy, in part by signalling to other states democratic intentions, particularly regarding the reality or seriousness of any commitment to the use of force (George and Bennett 2005, 54-57).

As is clear, most of the work done across these periods has adopted a social scientific approach. Yet the scientific emphasis on quantification, statistics, models and case studies may have obscured the extent to which the evolution of research in the field is a consequence of 'democratic peace theory' having become a battleground for competing schools of international relations thought. As the scholarship indicates, the salience of the theory lies not just in its contribution to our understanding of democracy or international relations. It is provocative because it provides a methodologically robust, and therefore fundamentally powerful challenge to contemporary 'realists' who argue that the character of international relations is shaped more by the anarchic nature of the international system than by states' internal structures or norms. If democratic peace theory is true, then the claims by realists that states are condemned to exist in a condition of constant security competition, and thus permanent potential conflict, are seriously undermined (Rosato 2003, 585). Democratic peace theory's best-supported finding would seem to vindicate liberal Kantian assumptions about

\footnotetext{
${ }^{3}$ On the limitations of definitions see, for example, Kegley and Hermann $(1999,101)$, who argue the definition of military intervention is not clear; Spiro (1994) who makes a similar claim regarding the vagueness of the definition of democracy, liberalism and war. On the merits of various indices, such as the Polity data set and Correlates of War (COW) see Munck and Verkuilen (2002).

${ }^{4}$ See, for example, Doyle (1986); Russett and Oneal (2001).

5 As Elman (1997) argues, part of the problem has been in case selection, with an overemphasis on cases involving the United States and excessive focus on the Fashoda Crisis and the Spanish-American war.
} 
the potential for a peaceful international order once democratic government is sufficiently diffused across the globe. And indeed most critics of the theory, whether they question the methodological integrity or validity of the findings or attempt to provide alternative causal accounts for the absence of conflict, have in fact been realists who have clearly recognised such far-reaching implications. ${ }^{6}$

Nevertheless, even if the dyadic theory of democratic peace holds good against realist critiques, explanation is still required for the apparent lack of any tendency toward monadic peacefulness. According to the Kantian perspective, authoritarian regimes may order submissive subjects into endless conflicts for the sake of power, dynastic ambition or personal honour, but democratic leaders serving a sovereign people are generally unwilling to command citizens to sacrifice their lives for anything less than national defence. And yet democracies have in fact been involved in many wars, great and small, over the centuries, not all of which were wars of national defence or emergency.

This apparent double nature of democracy with regard to war has raised many questions about the causes of the wars that democracies in fact prosecute and whether, among them, may be a powerful moral commitment to promoting democratic regimes abroad as the securest path to international peace. It was indeed the claim of Doyle (1986) that the two-fold liberal legacy of liberal peace and liberal 'impudence' in waging wars against illiberal states could be explained by Kant's liberal internationalism. And Russett and Oneal (2001) concluded their influential book Triangulating Peace by noting the need to widen the 'zone of stable pace' by the successful integration of Russia and China into the Kantian system. Yet such an ambitious long-range goal of regime change in non-democratic nations might make democratic peace theory seem, from a realist point of view, noble yet dangerous, encouraging democratic leaders toward policies that provoke rather than avoid conflict, with unpredictable consequences.

Liberal democratic regimes generally presume themselves to be, almost by definition, devoted to peace, and to extending, where possible, the zone of democratic peace internationally. For that very reason, the moral questions raised by war and the realities of prosecuting wars pose particularly difficult challenges for them. This is especially so because, in the conduct of wars, democracies inevitably shift toward quasi-monarchic principles, surrendering or suspending temporarily important democratic freedoms for the expeditious

\footnotetext{
${ }^{6}$ On methodological based critiques see Gatzke (1998; 2000); on substantive critiques see Mearsheimer (1990), Copeland (1996), Gates et al (1996), Rosato (2003), Layne (1994), Spiro (1994), Faber and Gowa (1997), Gowa (1995), Thompson (1996), Kegley and Herman (1999). See Ray (2003, 241) on how in the Lakatosian sense, 'realism and/or neorealism has been "falsified"'
} 
conclusion of conflict. This raises questions concerning the way democracies return to their core principles on completion of conflict, for it is clear that mature democracies have shown surprising resilience in confronting the most pressing international dangers without succumbing to fundamental regime change. What accounts for such resilience, and is it inevitable? What limits exist on leadership freedoms and opportunities, what constraints are maintained?

Despite wartime controls, democracies typically continue to hold elections and remain subject to the criticism of media and opposition, making democratic involvement in war much more politically fraught than in non-democratic countries. All governments at war must manage or control public opinion and support, but the nature of democracy makes this a pressing moral, as well as practical, concern. There are also important questions to be asked about how democracies conduct, or are expected to conduct (both militarily and morally), their wars, and whether democratic constraints provide differential advantages or disadvantages with respect to non-democracies. Related to such questions is the issue of how democracies end the wars they are in, especially since the historical record provides examples ranging from insistence on the unconditional surrender of the enemy, to negotiated termination, to more or less dignified or undignified withdrawals that amount to tacit surrender. Of significance here, obviously, is the issue of different responses to the types of wars democrats fight, for example conventional wars (whether large or small scale) versus insurgent actions.

\section{Articles in this special edition}

In this special edition we explore some of these questions and conundrums that war raises for democracies. We do so in part by revisiting, in a critical spirit, the theoretical foundations of liberal-democratic peace theory, and in part by addressing, with theoretical sensitivity and empirical rigour, some central questions about the involvement of democracies in war specifically: 1) how and why democracies enter into the wars they do; 2) how democratic institutions maintain their resilience and effectiveness in the midst of major wars; and 3) how democracies exit or end the wars they become involved in.

In the first theoretical paper, John Kane addresses the idealism-realism dilemma that plagues liberal democratic foreign policy, inviting charges of either naïveté or hypocrisy depending on which branch of the dichotomy appears predominant in any particular instance. He uses the history of the modern world's first and most powerful democracy, the United States, to illustrate this dilemma and explores its theoretical roots through an analysis of the 
work of Kant. Kant laid down the influential moral-political ideal of a democratic peace but, according to Kane, posited so stark a theoretical gulf between morality and politics as to make the ideal seem unreachable, even as it pointed the way to a genuinely ethical-practical foreign policy founded in political prudence.

In a second theoretical essay, Haig Patapan also returns to Kant but to argue that the most prominent democratic peace scholars, in constructing a virtuous triangle of democracy, commerce and international law, have fundamentally misinterpreted Kant's work. Most provocatively, he returns to the work of Montesquieu to suggest that it may not after all be democracy that conduces most readily to international peace but rather commerce, which Montesquieu argued tended to soften manners and defuse tensions among nations. If this should be so, profound consequences follow for democratic international relations, moderating demands for democratisation and promoting bilateral relations with nondemocratic powers.

In the third paper in this collection, John Owens tackles the issue of democratic resilience during major wars. On the face of it, war presents an immediate risk to democratic liberties and perhaps to democracy itself, since prosecuting a war requires the centralisation and concentration of power and a certain curtailment of civil liberties, turning the democracy, as we noted above, into a quasi-monarchical or quasi-dictatorial regime. Owens uses a detailed comparative study of British, Australian and American wartime executives during World War II to demonstrate that parliaments and Congress not only continued to exist but asserted themselves, more or less effectively, to hold executives to account. Thus even in conditions approaching total war, key democratic institutions proved remarkably resilient.

In the fourth paper, David Rousseau, A. Trevor Thrall, Marcus Schulzke and Steve Sin examine the question of how democracies generally become entangled in international conflicts, major or minor, either through being drawn into them willy-nilly or themselves provoking them. Their focus is on how democratic leaders must and do manage domestic politics and public opinion by offering justifications at each stage of the conflict - from dispute, to crisis, to war and ultimately to final settlement. The authors offer a subtle and wide-ranging analysis of the crucial intersection of domestic and international politics in times of war, arguing that leadership management strategy is critically dependent on a combination of factors, specifically: the stage the conflict has reached; the domestic institutional structure; and the level of mobilised domestic opposition.

In the fifth paper, Gil Merom looks more specifically at the issue of democratic involvement in 'asymmetric' counterinsurgency conflicts, the conduct of which frequently 
offends liberal democratic sensibilities. Merom considers the prima facie counterintuitive fact that democratic governments continue to engage in such conflicts even after repeated experience of very negative reactions and effective opposition to them from within their own polities. He solves the puzzle by arguing that governments, while still believing in the value of conducting such wars, have learnt through bitter experience to isolate their effects from societal forces. The various means employed - advanced military technology that minimises ground casualties and collateral damage; a turn to professional armies; and improved control of news media - turn such conflicts, in Merom's view, into curiously 'asocial' wars.

In the final paper, Adam Lockyer looks at how democracies exit wars, giving particular attention to the role of opposition parties in determining how and whether wars are terminated. In democratic polities, public opinion is expected to constrain and pressure government, and Lockyer shows that opposition political parties play a vital role as a conduit through which society can shape policy even in war situations. He argues that oppositions may be instrumental in promoting war termination in three ways: through what he calls elitecuing, by applying electoral pressure, or by winning election and assuming government.

These articles are not, of course, intended to be exhaustive of the subject of democracy and war. Despite the volume of literature already extant in the field, there remain aspects of this perennially important and often troubling theme that have yet to be adequately explored. Nevertheless, we believe that each article in this special edition will, in its distinctive way, provide instructive insights and raise significant issues worthy of further consideration.

\section{References}

Bueno de Mesquita, Bruce, and David Lalman 1992, War and Reason: Domestic and International Imperatives, New Haven, CT: Yale University Press.

Chan, S. 1984, "Mirror, Mirror on the Wall ... Are the Freer Countries More Pacific?” Journal of Conflict Resolution 28(4): 617-48.

Copeland, Dale C. 1996, "Economic Interdependence and War: A Theory of Trade Expectations," International Security 20(4): 5-41

Dixon, William J. 1994, "Democracy and the Peaceful Settlement of International Conflict," American Political Science Review 88(1): 14-32.

Doyle, Michael W. 1983, "Kant, Liberal Legacies, and Foreign Affairs," Philosophy and Public Affairs 12(3): 205-35.

Doyle, Michael W. 1986, "Liberalism and World Politics," American Political Science Review 80(4): 1151-69.

Elman, Miriam (ed.) 1997, Paths to Peace: Is Democracy the Answer? Cambridge, MA: MIT Press.

Farber, Henry S. and Joanne Gowa 1997, "Common Interests or Common Polities? Reinterpreting the Democratic Peace,” The Journal of Politics 59(2): 393-417.

Gartzke, Erik 1998, "Kant We All Just get Along? Opportunity, Willingness, and the Origins of the Democratic Peace," American Journal of Political Science 42(1): 1-27.

Gartzke, Erik 2000, "Preferences and the Democratic Peace," International Studies Quarterly 44(2): 191-212. 
Gates, Scott, Torbjørn L. Knutsen and Jonathon W. Moses 1996, "Democracy and Peace: A More Skeptical View," Journal of Peace Research 33(1): 1-10.

George, Alexander L. and Andrew Bennett 2005, Case Studies and Theory Development in the Social Sciences, Cambridge, MA: MIT Press.

Gowa, Joanne 1995, “Democratic States and International Disputes,” International Organization 49(3): 511-22.

Hegre, Harvard 2000, "Development and the Liberal Peace: What does it take to be a Trading State?" Journal of Peace Research 37(1): 5-30.

Hess, Andreas 1999, "The Economy of Morals and Its Applications: An Attempt to Understand Some Central Concepts in the Work of Albert O. Hirschman," Review of International Political Economy 6(3): 338359.

Kegley, Charles W. and Margaret R. Hermann 1999, "Putting Military Intervention into the Democratic Peace: A Research Note," Comparative Political Studies 30(1): 78-107.

Layne, Christopher 1994, "Kant or Cant: The Myth of the Democratic Peace," International Security 19 (Fall): $5-49$.

Maoz, Zeev and Nasrin Abdolali 1989, "Regime Types and International Conflict, 1816-1976.” Journal of Conflict Resolution 33(1): 3-35.

Maoz, Zeev and Bruce M. Russett 1993, "Normative and Structural Causes of Democratic Peace, 1946-1986," American Political Science Review 87(3): 624-38.

Mearsheimer, John J. 1990, "Back to the Future: Instability in Europe after the Cold War," International Security 15(1): 5-56.

Munck, Gerardo and Jay Verkuilen 2002, "Conceptualizing and Measuring Democracy: Evaluating Alternative Indices," Comparative Political Studies 35(1): 5-54.

Ray, James Lee 1995, Democracy and International Conflict: An Evaluation of the Democratic Peace Proposition, Columbia: University of South Carolina Press.

Rosato, Sebastian 2003, "The Flawed Logic of Democratic Peace Theory," American Political Science Review 97(4): 585-602.

Rummel, R. J. 1979, Understanding Conflict and War, Vol. 4: War, Power, Peace, Beverly Hills, London: Sage.

Russett, Bruce 1993, Grasping the Democratic Peace: Principles for a Post Cold War World, Princeton, NJ: Princeton University Press.

Russett, Bruce M. and John R. Oneal 2001, Triangulating Peace: Democracy, Interdependence, and International Organizations, New York: Norton.

Schultz, Kenneth A. 2001, Democracy and Coercive Diplomacy, Cambridge: Cambridge University Press.

Spiro, David E. 1994, “The Insignificance of the Liberal Peace,” International Security 19(2): 50-86.

Swaney, James A. 1983, "Rival and Missing Interpretations of Market Society: A Comment on Hirschman," Journal of Economic Literature 21(4): 1489-1493.

Thompson, William R. 1996, "Democracy and Peace: Putting the Cart before the Horse?" International Organization 50(1): 141-74.

Van de Haar, Edward 2010, “The Liberal Divide over Trade, Peace and War," International Relations 24(2): 132-54.

Waltz, Kenneth N. 1979, Theory of International Politics, Reading, MA: Addison-Wesley.

Weart, Spencer R. 1998, Never at War: Why Democracies Will Not Fight One Another, New Haven, CT: Yale University Press.

Weede, Erich 1984, “Democracy and War Involvement," Journal of Conflict Resolution 28(4): 649-664.

Wenar, Leif and Branko Milanovic 2009, “Are Liberal Peoples Peaceful?” The Journal of Political Philosophy 17(4): 462-486.

Williams, Michael C. 2001, "The Discipline of the Democratic Peace: Kant, Liberalism and the Social Construction of Security Communities," European Journal of International Relations 7(4): 525-53. 